\title{
Meditation: a modulator of the immune response to physical stress? A brief report
}

\author{
E E Solberg, R Halvorsen, J Sundgot-Borgen, F Ingjer and A Holen \\ Ullevål University Hospital, Department of Medicine, Oslo, Norway
}

\begin{abstract}
Objective - To test the hypothesis that stress reducing techniques such as meditation alter immune responses after strenous physical stress.

Methods - The hypothesis was tested by studying six meditating and six non-meditating male runners in a concurrent, controlled design. After a period of six months with meditation for the experimental group, blood samples were taken immediately before and after a maximum oxygen uptake test $\left(\dot{\mathrm{V}} \mathrm{O}_{2 \max }\right)$.

Results - The increase in $\mathrm{CD8}+\mathrm{T}$ cells after $\dot{\mathrm{V}} \mathrm{O}_{2 \max }$ was significantly less in the meditation group than in the control group $(P=\mathbf{0 . 0 4})$. The amount of $\mathrm{CD2}+$ cells doubled after $\mathrm{VO}_{2 \max }$, mainly because of a rise in the $\mathrm{CD8}+$ fraction.

Conclusions - Meditation may modify the suppressive influence of strenous physical stress on the immune system. (Br J Sports Med 1995; 29: 255-257)
\end{abstract}

Keywords: lymphocytes; stress; meditation; immunomodulation

Research indicates that various forms of stress can influence immune function in humans and animals. ${ }^{1-8}$ After stressful events, reduced lymphocyte proliferative responses and altered absolute and relative numbers of lymphocyte subsets have been reported. The influence on the immune system takes place either when the stress is of long duration or when a maximum workload exercise is applied., ${ }^{2}$ Halvorsen and Vassend ${ }^{5}$ showed a reduction in the large, probably activated $\mathrm{CD} 4+$ (mostly helper phenotype) T cells and CD8 + (mostly cytotoxic phenotype) $\mathrm{T}$ cells following psychological stress. Other investigators have found decreased proportions of $\mathrm{CD} 4+\mathrm{T}$ cells $s^{6}$ and a decreased $\mathrm{CD} 4+/$ $\mathrm{CD} 8+\mathrm{ratio}^{2,6,8}$ during heavy exercise. The immune system may be an interesting index for monitoring overtraining. ${ }^{9}$

Combined with reports of increased susceptibility to infections among athletes, intense physical training may be implicated in the decrease of the normal immune response towards infectious agents. Another suggestion has been that the observed changes in immune cells and their reactions constitute a normal adaptation to stress.

If stress influences the immune cells, will a stress reducing technique such as meditation, practised during a longer period, moderate the responsiveness of $\mathrm{T}$ lymphocytes when the organism is exposed to strenous

Address for correspondence: Dr E E Solberg MD, Ullevål University Hospital, Department of Medicine, Oslo, Norway physical stress? The aim of this study was to investigate whether or not preparation with meditation changes the relative numbers of $\mathrm{CD} 4+$ and $\mathrm{CD} 8+\mathrm{T}$ cells after strenous physical stress, demonstrating an influence on the immune system.

\section{Methods}

This was a study of two groups of runners - one practising meditation, the other serving as control.

\section{Subjects}

The subjects were invited from the running milieu in Oslo. They were all males exercising regularly and taking part in at least one running competition longer than 10000 metres each year. Median age was 47 years (range 43-49) in the meditation group $(n=6)$ and 38 years (range 27-46) in the control group $(n=6)$.

Six months before this concurrent study was carried out, the runners were randomly assigned to two groups. In a seven weeks course one group was instructed to practise meditation (ACEM meditation, ${ }^{10,11}$ a non-cult technique using repetition of a simple sound practised in 30 min sequences regularly at home). The other group practised no kind of meditation or any formal relaxation technique.

From these two groups the first six consecutive male subjects in the experimental group and the first six in the control group who were tested for maximum oxygen uptake $\left(\mathrm{VO}_{2 \max }\right)$ were included in the study. This limitation was made for logistical reasons.

There were no statistically significant differences in baseline $\dot{\mathrm{VO}}_{2 \max }$ values either six months before the study or during the study: (1) before the study: median $56.0 \mathrm{ml} \cdot \mathrm{min}^{-1} \cdot \mathrm{kg}^{-1}$ (range 43.7-66.1) in the group which later learned the meditation technique, and 57.5 $\mathrm{ml} \cdot \mathrm{min}^{-1} \cdot \mathrm{kg}^{-1}$ (range 45.8-75.9) in the control group; (2) during the study: median $56.2 \mathrm{ml} \cdot \mathrm{min}^{-1} \cdot \mathrm{kg}^{-1}$ (range $42.8-65.5)$ in the meditation group, and 58.1 $\mathrm{ml} \cdot \mathrm{min}^{-1} \cdot \mathrm{kg}^{-1}$ (range 46.3-73.1) in the control group. The runners in the meditation group completed a questionnaire about their meditation compliance which was satisfactory, with a mean of 24 meditation sessions per month during the intervention period. As an additional compliance control five of the six stated in the questionnaire that they had experienced parasympathetic signs of relaxation during meditation, indicating satisfactory meditation practice. 


\section{Design}

A concurrent design was used. The subjects were tested for their maximum oxygen uptake. Blood samples were taken immediately before and after the $\mathrm{VO}_{2 \max }$ test, and the number of CD2 + (pan T cells), CD4 +, and CD8 + $\mathrm{T}$ cells was counted. ${ }^{12}$

To correct for possible confounding influences of recent stressors, exposure to stressful life events during the six months before the study was recorded. The scoring of each event ranged from 0-8 (where 0 is "not at all distressing") in a shortened version ${ }^{13}$ of the life events stress test. ${ }^{14}$

\section{Procedures}

Maximum oxygen uptake

$\mathrm{VO}_{2 \max }$ was measured during running on a motor driven treadmill at $3^{\circ}$ uphill inclination according to the procedure described by Åstrand and Rodahl. ${ }^{15}$

\section{Blood samples}

An EDTA whole blood sample was drawn from each subject immediately before and after the treadmill exercise. The blood samples were chilled and analysed the same day. M450 monosized polystyrene microspheres coated with monoclonal antibodies directed against $\mathrm{T}$ cell antigens $\mathrm{CD} 4+, \mathrm{CD} 8+$ and $\mathrm{CD} 2+$, purchased from Dynal, Oslo, were used. Monoclonal antibodies specific for the B cell antigen CD19 (clone $\mathrm{ABI} / \operatorname{IgM}$ ) were produced by S Funderud, and directly coated on M450 as described. ${ }^{16}$ Preparations for counting $T$ cell subsets and $B$ cells were prepared as described by Brinchmann et al..$^{12}$ Briefly, whole blood with EDTA was chilled $\left(+4{ }^{\circ} \mathrm{C}\right)$ and placed on a rocking/rolling rack. Samples of blood were mixed with the M450 coated with monoclonal antibodies and rotated at $+4{ }^{\circ} \mathrm{C}$. By applying a magnet, rosetting cells were selected and the supernatant discarded. After washing, zaponin and acridin orange were added. The fluorescing cells were counted with an immunofluorescence microscope.

\section{Statistics}

Differences between groups were tested by using two tailed Student's $t$ tests.

\section{Results}

In both groups, the total number of T cells (CD2 + cells) doubled after exercise. This was mostly due to the rise in CD8 + T cells, while the CD4 + T cells remained stable. The increase in CD8 $+\mathrm{T}$ cells after exercise was greater $(P=0.04)$ in the control group than in the meditation group. Figure 1 shows the mean values \pm 1 $\mathrm{SD}$ of $\mathrm{CD} 2+, \mathrm{CD} 4+$, and $\mathrm{CD} 8+\mathrm{T}$ cells before and after the exercise test in the two groups. The percentage of $\mathrm{CD} 4+\mathrm{T}$ cells of the total T cells was decreased in both groups. There was also a decrease in the CD4+ / CD8 + ratio after exercise in both groups (Table 1 ). None of the changes was statistically significant. The life event stress exposure was small in both groups and showed no statistically significant difference between the groups.

\section{Discussion}

The major finding of this study was a significantly smaller increase in CD8 $+\mathrm{T}$ cells in the meditation group after strenous physical stress. There was a nonsignificant decrease in the $\mathrm{CD} 4+/ \mathrm{CD} 8+$ ratio and in the percentage of $\mathrm{CD} 4+\mathrm{T}$ cells (mostly helper $\mathrm{T}$ cells) of the total $\mathrm{T}$ cell count in both groups.

This lower increase of CD8 $+\mathrm{T}$ cells in the relaxation group may indicate a modifying influence on the immune response to strenous physical stress due to practice of meditation. There was, however, no significant difference between the groups in the $\mathrm{CD} 4+$ / $\mathrm{CD} 8+$ ratio, although there was a slight tendency towards a lower ratio in the control group after exercise. For both groups a decrease in the proportion of CD4+ cells in the total $\mathrm{T}$ cell pool was found after exercise. No significant difference between the groups was observed. Thus no influence of meditation on this variable could be observed. The markedly decreased CD4 + /CD8 + ratio and the low percentage of $\mathrm{CD} 4+\mathrm{T}$ cells after exercise indicate that exercise may suppress the cellular immune system, probably temporarily.

Much attention has been directed towards various forms of stress as potent suppressors of the immune response. The actual mechanisms for this immunomodulation are unknown. Several possible mechanisms of stress induced immunomodulation are possible, including the release of corticosteroids, catecholamines, immunologically active substances like interleukin-1, $\beta$ endorphin, interferon, ${ }^{7}$ or other direct immunosuppressive influences on the immune cells. We do not have data to pursue this further.

It seems unlikely that the selection of the subjects would be biased with regard to differences in the immune system. The results of the $\mathrm{VO}_{2 \max }$ tests were practically the same in the two groups. The small number of participants in the present study may influence the results towards a negative outcome because of lack of statistical power. Additional stress might have been a possible source of misintepretation of the results. However, no significant difference was seen in life events stresses between the groups in the present study. Both had been exposed to a minimum of such stresses, probably insufficient to have a measurable influence on the immune response. A difference between the groups in exercise induced changes in plasma volume, thus distorting the cell counts per $\mathrm{ml}$ of blood, is unlikely in a controlled design during the short $\dot{\mathrm{VO}}_{2 \max }$ test.

\section{Conclusions}

Strenous physical stress constitutes a probable suppressive influence on the immune system. Meditation may modify this suppression. Further studies are needed to elucidate the mechanisms for the suppressive effects of excercise and possible modulating effect of stress reducing techniques. 


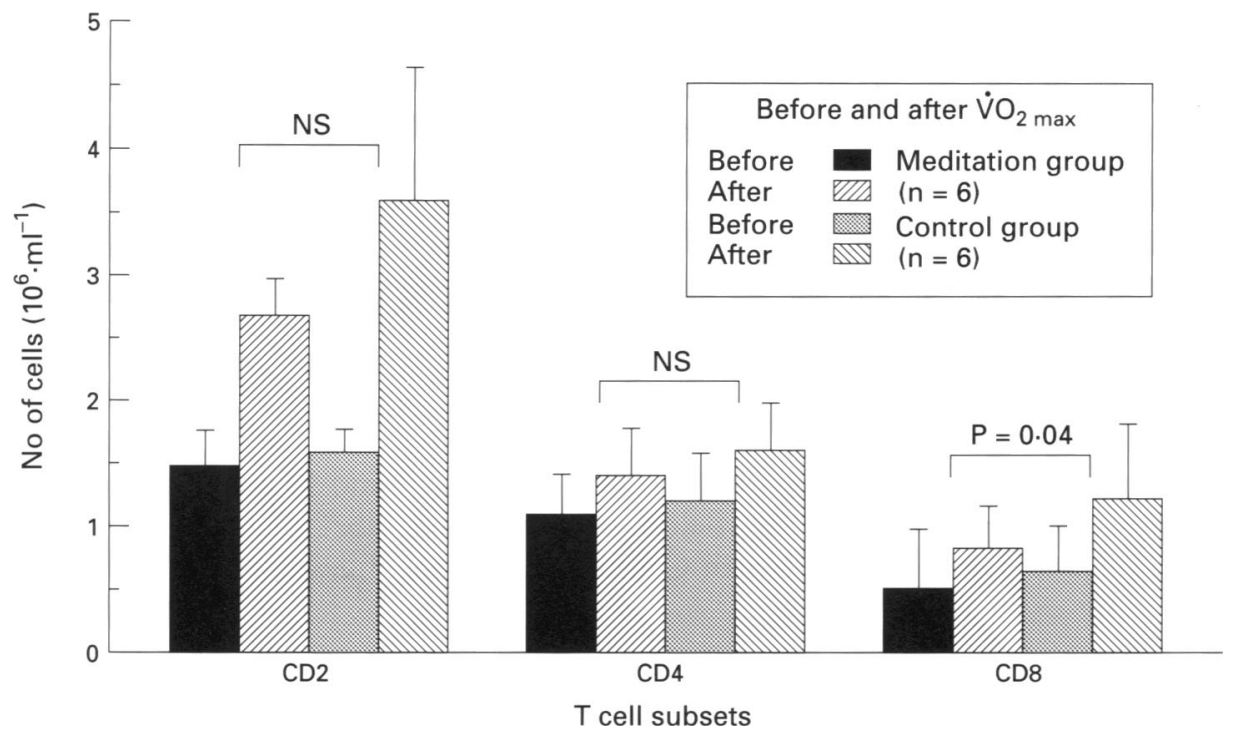

Figure 1. The effect of physical stress $\left(\dot{\mathrm{V}} \mathrm{O}_{2 \max }\right)$ and meditation on some $\mathrm{T}$ cell subsets

Table 1. Effect of physical stress on CD4/CD8 ratio and percentages of CD4 and CD8 cells of total T cell count (CD2)

\begin{tabular}{|c|c|c|c|c|c|c|}
\hline \multirow[b]{3}{*}{$\begin{array}{l}\text { All } \\
\text { subjects } \\
(\mathrm{n}=12)\end{array}$} & \multicolumn{3}{|c|}{ Before $\dot{\mathrm{V}}{ }_{2 \max }$} & \multicolumn{3}{|c|}{ After $\dot{\mathrm{VO}}_{2 \max }$} \\
\hline & \multicolumn{3}{|c|}{$\mathrm{CD} 4 / \mathrm{C} 8 \mathrm{CD} 4 \% \mathrm{CD} 8 \%$} & \multicolumn{3}{|c|}{ CD4/CD8 CD4 \% CD8 $\%$} \\
\hline & 2.2 & 77 & 32 & 1.5 & 51 & 30 \\
\hline $\begin{array}{l}\text { Meditation } \\
\text { group } \\
(n=6)\end{array}$ & 2.3 & 78 & 28 & 1.8 & 54 & 27 \\
\hline $\begin{array}{c}\text { Control } \\
(n=6)\end{array}$ & 2.0 & 75 & 37 & 1.3 & 47 & 34 \\
\hline
\end{tabular}

No significant differences observed

\section{Acknowledgements}

The authors wish to thank Hafslund Nycomed for financial support, the ACEM School of Meditation for the instruction in meditation, Mitch Loeb for help with the figure, and Irene Andersen for excellent technical assistance.

\section{References}

1 Jemmott JB, Locke SE. Psychological factors, immunological mediation and human susceptibility to infectious diseases: how much do we know? Psychol Bull 1984; 95 : 78-108.

2 Landmann RMA, Muller FB, Perini CH, Wesp M, Erne P, Buhler FR. Changes of immunoregulatory cells induced by psychological and physical stress: relationship to plasma catecholamines. Clin Exp Immunol 1984; 58 : 127-35.
3 Eskola J, Ruriskanen O Soppi E, Viljanen MK, Jarvinen M Toivonen $\mathrm{H}$, et al. Effect of sports stress on lymphocyte transformation and antibody formation. Clin Exp Immunol 1978; 32 : 339-45.

4 Hedfors E, Holm G, Ivansen M, Wahren J. Physiological variation of blood lymphocyte reactivity: T-cell subsets, immunoglobuline production and mixed lymphocyte reactivity. Clin Immunol Immunopathol 1983; 27: 9-14.

5 Halvorsen R, Vassend O. Effects of examination stress on some cellular immunity functions. J Psychosom Res $1987 ; 31$ : 693-701

6 Tvede N, Pedersen BK, Hansen FR, Bendix T, Christensen LD, Galbo $\mathrm{H}$, et al. Effect of physical exercise on blood mononuclear cell subpopulations and in vitro proliferative responses. Scand J Immunol 1989; 29: 383-9.

7 Fitzgerald L. Exercise and the immune system. Immunol Today $1988 ; 9$ : 337-9.

8 Tchorzewski H, Lewicki R, Majewska E. Changes in the helper and suppressor lymphocytes in human peripheral blood following maximal physical exercise. Arch Immunol Ther Exp 1987; 35: $307-12$.

9 O'Brien M. Overtraining [abstr]. FIMS World Congress of Sports Medicine, Athens, 1994.

10 Holen A, ed. The psychology of silence, 6th ed. Oslo: Dyade forlag, 1989 (in Norwegian).

11 ACEM international newsletter, 1986; 6, no 1. Oslo: ACEM.

12 Brinchmann JE, Vartdal F, Gaudernack G, Markussen G, Funderud $\mathrm{S}$, Ugelstad J, et al. Direct immunomagnetic quantification of lymphocyte subsets in blood. Clin Exp Immunol 1988; 71 : 182-6.

13 Holen A. A long-term outcome study of survivors from a disaster. Oslo: University of Oslo, 1990. [Doctoral dissertation.]

14 Holmes TH, Rahe RH. The social readjustment scale. J Psychosom Res 1967; 11: 213-8.

15 Asstrand PO, Rodahl K. Textbook of work physiology. New York: McGraw-Hill, 1987.

16 Funderud S, Nustad K, Lea T, Vartdal F, Gaudernack G, Stenstad $P$, et al. Fractionation of lymphocytes by immunomagnetic beads. In: Klaus GGB, ed. Lymphocytes: a practical approach. Oxford: IRL press, 1987. 